\title{
Horizontalism, Public Assembly, and Republican Politics
}

Stuart White

\section{Introduction}

'Whether it fizzles with the first snowfall or develops into a true counterweight to the Tea Party, Occupy Wall Street will go down as the first protest movement in recent memory to shine a critical light on the staggering levels of economic inequality in the United States.' So begins Steven Mazie's article, 'Rawls on Wall Street', published in the New York Times online commentary section on October 212011 (Mazie 2011). Mazie's words speak to the impressive impact that the Occupy movement initially made in the US, and to the hopes it raised. Moreover Occupy was by no means confined to the US. And Occupy is only one expression of a form of political action - 'networked horizontalism' - that has become familiar in recent years. What is the significance of this kind of action for a republican politics? Republican political theory often focuses primarily on institutions. However, in recent years some scholars, such as Karma Nabulsi and Alex Gourevitch, have explored republicanism as a political practice, a practice that finds itself sometimes - indeed, frequently - located in a polity that is not itself republican (Nabulsi 2008, Gourevitch 2015). ${ }^{1}$ My focus here has something in common with this focus on practice, on the doing of republicanism in non-republican polities, although the practices under discussion here draw at least some of their significance from imagined institutional changes, and arguably require institutional changes to have more influence.

I start in section 1 by clarifying the ideal of republican democracy and one major contemporary challenge to this ideal. Recent decades have seen a growth of oligarchic power in capitalist democracies such as the USA and the UK. An effective politics of republican democracy must aim to contest oligarchy. In section 2 I then provide a brief overview of 
Occupy and networked horizontalism and consider how we might view political action of this kind as a prefigurative republican politics. ${ }^{2}$

Sections 3-5 then consider three different ways Occupy and similar forms of action might further the contesting of oligarchy. Taking the existing constitutional order, with its oligarchical features, as a given, we might first understand Occupy and similar initiatives as a defensive republican politics: as a way of trying to make maximum use of existing democratic possibilities (including civil disobedient possibilities) to counter the influence of corporations and wealthy individuals.

Occupy and similar initiatives can also be understood, however, as constitutional republican politics. Section 4 outlines and explores the idea that such action can facilitate a transformation of institutions with a view to weakening oligarchical power. I discuss how this potential impact on institutions may go alongside a transformative effect on citizens. By modelling democratic self-government in practice, Occupy-type action can perhaps help to create or consolidate amongst citizens a sense of their proper, sovereign power. Section 5 briefly considers whether we might regard Occupy-type action as a form, or beginning of, transnational republican politics. Section 6 draws the argument's threads together and presents a sceptical challenge to the idea of Occupy as a constitutional republican politics. This prompts a tentative conclusion on the interdependency between Occupy and similar initiatives, conceived as constitutional republican politics, and institutions that shape opportunities for constitutional renewal.

\section{Republican democracy and the problem of oligarchy}

The normative starting-point for this discussion is an ideal of republican democracy. What do I mean by this, and in particular by the adjective 'republican'? I sketch an answer here that I seek to develop in more depth elsewhere. ${ }^{3}$ 
First, I take a democracy to be a political system in which there is significant equality of opportunity for political influence in conditions of free expression, association and open political competition. So we can imagine that policy is made by elected representatives and/or direct popular votes with individuals free to make arguments for and against alternatives and to organise freely with others to compete in elections and other votes. In addition, to help ensure significant, and not merely formal, equality of opportunity for political influence, there is substantial equality of resources and/or effective constraints on how economic advantage can be used to influence policy decisions. Against this backdrop, I conceive of a specifically republican democracy as having at least three further features:

(1) Deliberation to the common good. In a republican democracy, there is properly a concerted effort to orient the use of state power to the common good. Under conditions of free and open public deliberation, citizens seek to identify laws and policies that serve the shared basic interests of all in goods such as life, liberty and economic opportunity and equality of civic and political standing. ${ }^{4}$ Citizens offer reasons to one another in democratic decision-making that track these interests.

(2) Democracy's priority over property. Orientation to the common good implies that individuals' rights to income and wealth are established in accordance with rules about production and acquisition that reflect popular, deliberated judgments about what best secures the common good. If a given property rights regime predictably leaves citizens without security in life or liberty, for example, then the citizenry has the right (indeed, duty) to replace it with a regime that better secures these interests. In this sense, there is no right to private property that is morally prior, or superior, to the common good. 
(3) Active popular sovereignty. In a republican democracy, the citizenry forms an active popular sovereign, willing and able to exercise ongoing, creative authority over society's basic structure (Rawls 1999, 6-10).

Judged by this normative standard, the real-world democracies of many nations in the Euro-Atlantic region, such as the USA and UK, have serious flaws. One is the degree to which policy-making is shaped by oligarchic power. A number of recent studies point to the growth of power of corporations and the wealthy. ${ }^{5}$ Oligarchic power is problematic from a republican democratic point of view because it: undermines significant equality of opportunity for political influence; skews decision-making away from what serves the common good, towards narrower class- or interest group-specific goods; creates and reinforces property rights rules that fail to serve the common good; and, as result of the above, may undermine the opportunity and willingness of citizens to act as members of a popular sovereign. ${ }^{6}$

It would take much more work to establish definitively that there has been a shift towards more oligarchic power in countries like the UK and the USA in recent decades. But the emerging evidence base is significant and makes the oligarchical shift thesis, as we might call it, a highly credible one. This thesis provides the context here for discussion of the way in which Occupy and similar kinds of action might serve republican democracy. Having set out this context, let us now clarify this kind of political action.

\section{Occupy, horizontalism, and prefigurative republican politics}

In July 2011 the activist magazine Adbusters issued an online call for 20,000 activists to 'occupy Wall Street' on September 17. The group would assemble, determine an answer to the question, 'What is our one demand?', and then stay put until the demand was met (Gerbaudo 2012, 108-111). Following the Adbusters call-out, established networks of activists on the ground in New York City started to meet in August 2011 to discuss what 
action to take (Gerbaudo 2012, 110-113, Graeber 2012, 3-54). This resulted in a demonstration and occupation of Zuccotti Park on September 17 2011. Interest in the occupation increased through social media, particularly in response to heavy-handed policing (Gerbaudo 2012, 116-121). ${ }^{7}$ On October 15 there was an international day of action encompassing Occupy initiatives in different nations. In the UK, Occupy London Stock Exchange (Occupy LSX) ended the day by pitching its tents outside St. Paul's Cathedral (Hill 2013, 89).

The idea of an occupation of public space, co-ordinated through electronic media, was not new. In May 2011, thousands of Spanish citizens camped out in public squares in protest at the state of Spain's political system and lack of economic opportunity. This followed an initial national demonstration orchestrated through social media. The protestors came to be known as the indignados. The indignados, in turn, were in part inspired by the example of the Egyptian revolution which involved a combination of call-outs on social media with the physical occupation of Tahrir Square. The wider phenomenon of horizontalism can claim many other precedents. As Eloïse Harding discusses, horizontalism was a defining feature of the alternative globalization movement that emerged in the 1990s and early 2000s (Harding 2012). Since 2011 we have seen further mobilisations involving major public occupations of public spaces such as in Turkey and Brazil in 2013 and in Hong Kong in 2014. Other notable public protests include student mobilizations in Chile in 2011 and in Quebec in 2012; the Black Lives Matter protests in the USA since 2014; and the 2016 'Nuit Debout' movement in France. These are by no means all following an 'Occupy model'. But they respectively have some features in common with the politics under discussion here. ${ }^{8}$

Within Occupy Wall Street, the initial idea of determining a single demand was set aside quite early on. Rather than asserting a specific demand, the movement asserted a democratic presence: 'We are the 99\%'. In adopting this slogan, Occupy also aimed to draw 
attention to what it perceived as a problem: the alleged conflict of interest in contemporary capitalism between the interests of the top $1 \%$ and the rest.

Typically, each camp used a general assembly as its sovereign body to determine rules and agree public statements. Beneath the level of the general assembly, working groups tackled specific issues (Graeber 2012, 23-54, 227-232, Kinna, Prichard, and Swann forthcoming). Decision-making was characterized by use of 'consensus' methods rather than majority voting. Larger camps, such as Occupy Wall Street and Occupy LSX, became sites of discussion, with many daily meetings to consider aspects of the alleged political and economic crisis. Occupiers made use of internet tools so that many people outside the camps could follow what was going on and have a sense of participation. Participation was diverse in ideological terms, with some leftist participants feeling frustrated at the unwillingness of others to adopt a straightforwardly 'anti-capitalist' frame of analysis. Many faith groups engaged with Occupy. Many participants and supporters were also critical of perceived failures of inclusion in Occupy and to provide effective security in the protest camps, such as for women participants (McKeown 2011, Hill 2013, 93-95, Kinna, Prichard, and Swann forthcoming).

Occupy should not be seen in isolation but as one expression of a form of political action referred to as networked horizontalism. As indicated above, one key feature of this kind of action is the use of so-called consensus decision-making processes. These methods have been developed over a number of years and include a range of devices. Facilitators try to ensure that contribution to discussion is equitable. In the course of discussion, facilitators might take 'temperature checks' so that everyone can see how others feel about a particular proposal (e.g., the use of 'jazz hands' to indicate agreement). Those who disagree with a proposal can 'stand aside' or, if they feel the proposal is in deep contradiction with the group's values and aims, they may 'block' the proposal. This is an effective veto power, 
requiring the group to find a way to respond to a minority's reservations (Graeber 2012, 210227). Groups tend to eschew formal membership, with people free to come and go as they please. As Marianne Maeckelbergh discusses, persistent and irresolvable disagreements over objectives and tactics are dealt with by people dividing into different groups, but remaining within a network of communication and wider discussion (Maeckelbergh 2009, 99-138). ${ }^{9}$

Social media played an important role in creating and sustaining these networks. In addition to Occupy, one example is UK Uncut, which emerged in the UK in 2010 with an initial focus on the issue of corporate tax avoidance. At the outset, UK Uncut consisted of a small group of activists in London and a Twitter account. Following their first sit-in protest in a branch of Vodafone to protest alleged tax avoidance, a short film of the action was posted on the internet. This, and subsequent actions, encouraged the formation of other UK Uncut groups in other parts of the country, with the various groups keeping in touch through social media. The network had no formal leadership, local groups having autonomy. In the following months, similar networks emerged in other countries (Hill 2013, 40-41). Another example is the 'Spartacus' network of disability campaigners which emerged in the UK in 2012, effectively promoted by bloggers such as Sue Marsh and Kaliya Franklin ('Bendygirl'). Social media helped here to expand the range of people able to initiate political action, making possible a 'from-bed activism' for sick and disabled people who find it hard to get to meetings or public squares (Franklin 2010a, 2010b, Marsh 2010, 2012, Hill 2013, 102-105). Networked horizontalism does not necessarily imply a reliance on social media to the exclusion of 'offline' organizing, however. Accounts of Occupy Wall Street and the indignados emphasise the importance of local, offline relationships to the build-up of these protests (Gerbaudo 2012, 102-133, Graeber 2012, 3-54). This point has also been made in relation to UK Uncut (Hill 2013, 54). ${ }^{10}$ Moreover, these offline relationships do not 
(necessarily) unravel once a specific public mobilisation ends. They might have been extended and/or deepened as a result.

How does this networked horizontalism, sometimes accompanied by public assembly, constitute, or serve, a politics of republican democracy?

We will explore a range of possible answers to this question in what follows, but one initial answer is that it can constitute a form of prefigurative republican politics. This kind of political action itself embodies republican democratic values in its internal practices. In this sense, even in a polity that is not itself a republican democracy, it prefigures the kind of political community that republican democrats aspire to. In a recent study of what they call 'subterranean politics' in Europe, which encompasses Occupy and the indignados, Mary Kaldor and Sabine Selchow note this prefigurative aspect: '...the importance of the subjective experience of participating in politics in a new way, of reconstructing democracy out of one's own actions....the attempt to practice the kind of democracy that the participants imagine' (Kaldor and Selchow 2013, 88). Particularly noteworthy here are the egalitarian and deliberative internal practices. Armine Ishkanian, Marlies Glasius and Irum S. Ali interviewed individuals who participated in public square assemblies in Athens, Cairo, London, Moscow and Yerevan. One theme emerging in the interviews is the experience of equality within the assembly space: 'Strictly enforced methods for addressing the gathering meant that an academic and an unemployed labourer had the same amount of time at the microphone and the same opportunity to be heard' (Ishkanian, Glasius, and Ali 2013, 9). A second is the way the public square assemblies provided an opportunity for deliberation and for expanding one's thinking about social possibilities: 'One Occupy Moscow activist said, People wanted to talk to each other and to make their own decisions and not just go into the square and shout "Putin go away!" The assembly was the perfect place to get people to talk 
and for them to say what they want and to start to make projects inside society (Moscow, 7 June 2013)’ (Ishkanian, Glasius, and Ali 2013, 7).

Of course, those participating in such assemblies, or in other horizontalist forms of political action, do not necessarily identify as 'republican'. Nevertheless, this is not entirely a matter of projecting a label onto a diverse set of protests. In his recent analysis of the 'movement of the squares' between 2011 and 2016, Paulo Gerbaudo perceives a merger of anarchist organizing (horizontalism) with a 'left-populist' ideology centred on a contrast between people and oligarchy and a reassertion of popular sovereignty. He terms this combination citizenism and identifies an associated rhetoric around 'the citizen': 'chiefly understood as the possibility of individuals to be active members of their political community with an equal say in all important decisions....Citizenship is reclaimed as a source of dignity, in a world in which many feel humiliated by the arrogance of global financiers and an aloof political class' (Gerbaudo 2017, 7-8). ${ }^{11}$ This has clear affinities with the ideal of republican democracy set out above.

In short, Occupy and similar initiatives offer a way to do republicanism, or to be republican, in a non-republican society and, in so doing, points towards what a republican democratic polity would itself be like. However, a standard challenge to prefigurative politics is that while it may embody internally the values of a particular social or political ideal, in doing so it may lack instrumental effectiveness in challenging the existing political order. (Such is the usual Leninist criticism of anarchist and horizontalist politics.) Can Occupy-style politics meet this sceptical challenge? One way of exploring this question is to consider, as we will in the next three sections, how it might offer an effective response to the oligarchical shift.

\section{Defensive republican politics?}


If an oligarchical shift has occurred, and defines our current political context, is there a role for initiatives like Occupy and for horizontalism more generally in contesting this shift? In the next three sections I want to set out three ways in which such initiatives might be understood to counter the oligarchical shift. I begin in this section with an account of defensive republican politics. The basic idea here is that we have the political system we have, with its oligarchical features. But there are still possibilities, albeit some in the region of civil disobedience, for asserting anti-oligarchic, countervailing pressures.

Defensive contributions can take a range of different forms. Here are some contributions, which overlap to some extent.

First, horizontalist initiatives can put ideas into circulation in ways that change the terms of public debate. One recent study argues that Occupy prompted discussions of inequality in the US's mainstream media, leading to shifts in public opinion and the discourse of the political elite: 'Whether or not capitalism would be substantially reformed to the satisfaction of the Occupy protestors, it is remarkable that they were able to change the economic conversation in such a short time, using such highly personalized network organizations' (Bennett and Segerberg 2013, 191; see also Castells 2012, 191-197). It is also possible that horizontalist initiatives, using social media, can sometimes change the terms of elite discussion, even if the impact on wider public opinion is limited. The Spartacus initiative on the reform of welfare benefits for disabled people did affect coverage in the mainstream media and, although it probably did not impact much on underlying public opinion, arguably did generate renewed reflection within the political elite about the desirability of proposed benefit changes.

Civil disobedient protest might have a role in effecting these changes in the terms of public debate. In this case, the civil disobedience can be understood in broadly Rawlsian 
terms as action which involves law-breaking to communicate that a significant injustice is being committed so as to prompt deeper public reflection (Rawls 1999, 319-343).

Second, and related to the above, horizontalist action can change elected representatives' calculus of self-interest. Metaphorically, we may imagine our elected politicians seated in a room facing two monitors. On one monitor, they watch public opinion. On the other, they record incoming demands and complaints from corporate interests and wealthy funders. In order to advance their own prospects, they must be attentive to both monitors. ${ }^{12}$ Horizontalist campaigning can redress the balance of attention across the two monitors by intensifying the demands coming through on the public opinion monitor. This might involve making a neglected issue, such as corporate tax avoidance, more salient in public discussion, and/or articulating a policy, e.g., a Tobin tax, that elected politicians have thus far been wary of advancing.

The idea here is not to eschew the 'vertical' (the state, parties) for the 'horizontal', but to use the methods of the latter to bring new pressures to bear on, or within, the former. In Colin Crouch's view, political parties remain crucially important as associations that can compete for governmental power, a power which can still to some degree play a crucial role in checking the interests of corporations and the wealthy for the sake of a wider public good. However, a focus on traditional party politics needs, he argues, to be complemented (rather than replaced) by the development of non-party campaigns because '[p]arties which are not under pressure from causes will stay rooted in the post-democratic world of corporate lobbying...' (Crouch 2003, 111-112).

Taking this thought further, horizontalist initiatives can also contribute, directly or indirectly, to creating new parties or electoral alliances or to changing significantly the character of existing parties. As the Spanish case indicates, horizontalist and public assembly-based action can help bring about the rise of new parties. The relationship between 
the indignados and Podemos is by no means straightforward (Levi 2015), but the indignados created the context for the growth of Podemos and the electoral coalitions in which Podemos participates in city-level elections. Another possibility is of networked activists moving into an existing party so as to change its character, e.g., in the case of the Labour Party in Britain since 2015. Such moves can destabilise established relationships of power inside parties, at least temporarily weakening the influence that (for example) corporate interests exert over policy-making and public argument.

The defensive contribution of horizontalist political action need not work only through political parties and the formal political system, however. It can also involve various forms of direct action to limit the consequences of unjust policy. One might cite here the role of groups associated with the indignados in helping people resist home evictions due to mortgage difficulties, or the role of post-Occupy groups in the US in buying up and cancelling consumer debt (Prentoulis and Thomassen 2013, Fox Piven 2014). At least some of the direct action approaches used are civilly disobedient, and not all of these fit a Rawlsian model of legitimate civil disobedience, raising questions (which I lack space to consider here) about the ethical boundaries of legitimate civil disobedience in the context of the oligarchical shift. ${ }^{13}$

\section{Constitutional republican politics?}

Understanding Occupy and related initiatives purely in these defensive terms is, however, arguably too narrow. If the problem is that existing political institutions have, as per our working hypothesis, allowed for a shift towards oligarchy, then perhaps we need some kind of institutional innovation to help put oligarchic power more effectively in check. Perhaps, then, horizontalist political action can help effect institutional change of this kind? We can see this as a potentially constitutional republican politics. 
Developing this idea, we can see Occupy and horizontalism as potentially offering $a$ means by which to stake a public claim to, and generate public support and pressure for, institutional reforms that weaken oligarchical power (Castells 2012, 136-137). The camps and assemblies and other initiatives can potentially help build popular support for reforms and/or for processes that admit of reforms.

There is some evidence that movements like Occupy were centrally about this constitutional politics. Kaldor and Selchow find that a common feature across assembly movements in Europe is 'extensive frustration with formal politics as it is currently practised....current protests are not so much simply about austerity but about politics' (Kaldor and Selchow 2013, 84). Interestingly, this frustration was apparently expressed at times in terms that echo a republican democratic critique of oligarchic power: '...a German Occupy LSX activist told us, 'this is a screwed up system in terms of allowing people to have a say, policies for the common good, informed debate [and] media coverage' (London Study)' (Kaldor and Selchow 2013, 85). Italian protestors against a new high-speed rail link between Turin and Lyon spoke of 'political and economic oligarchies...inflicting contested choices on local populations and institutions...' (Kaldor and Selchow 2013, 85) Moreover, this frustration with 'politics' was linked to 'projects of collective re-imagining of democracy' (Kaldor and Selchow 2013, 88).

A constitutional politics perspective explicitly informed some commentators' and activists' responses to Occupy. In the USA, Lawrence Lessig argued that Occupy should see its objective as working to build public support for a constitutional convention to address the power of money in US politics (Greenwood 2011). Todd Gitlin suggested that Occupy is the start of a process of asserting the sovereignty of 'We the People' over the US political system, a continuation of the US's revolutionary tradition (Gitlin 2012). In the UK, a similar idea was developed by Dan Hind, a discussion to which I am much indebted (Hind 2012a, 
2012b, 2014). Drawing on the example of Occupy, Hind advocates the creation, through direct citizen action, of grass-roots citizen assemblies in parliamentary constituencies. He proposes that these meet to discuss constitutional issues. A movement of assemblies can then become the political base for making a series of demands for reform of the existing political system. Organizing on the basis of parliamentary constituencies might give the assemblies opportunity to exercise some leverage in elections.

An example that offers inspiration to Hind is that of post-crash Iceland (Hind 2012c; see also Castells 2012, 31-44). The severe financial crash there led in late 2008/early 2009 to a wave of demonstrations against the government (the 'pots and pans revolution'). Some protestors saw the underlying cause of the economic crisis in the excessive power of particular business interests. They demanded a new political constitution. The immediate effect of the demonstrations was a new election. This led to a new government which in turn agreed to establish a process to create a new constitution. At the heart of the process was a constitutional convention of 25 citizens elected from the general population (to the exclusion of MPs). As Hélène Landemore discusses, the convention met in 2011 and drafted a new constitution, making full use of the internet to crowdsource ideas and get feedback on its drafts (Landemore 2015). Although a referendum in 2012 indicated broad support for the draft constitution, the Icelandic parliament shelved the draft. Its possible adoption remains a source of ongoing contention.

The Icelandic case arguably shows both the power of popular political action, using informal networks, public assembly and internet-based discussion, to instigate and inform a constitutional reform process; and, at the same time, the importance of the underlying structures of the reform process in shaping outcomes (witness the power of the parliament to block enactment of the draft constitution). We will return to the latter point in the conclusion. ${ }^{14}$ 
There is a link between the prefigurative and constitutional aspects of initiatives like Occupy, one that is likely to work in part through the way such political action affects the attitudes and capacities of citizens. Constitutional republicanism evokes directly one of the core ideas of republican democracy, that of the citizenry as an active sovereign, able and willing to assert a creative, collective will over society's basic structure. But an active popular sovereign is not something that we can take for granted. Indeed, if a society is unjust, the structures of the unjust society may work to discourage active popular sovereignty. Perhaps they encourage 'individualism' in Tocqueville's sense, so that people focus on doing their best within the constituted order but do not see themselves as having responsibility for the political and economic system itself. ${ }^{15}$

Against this backdrop, Occupy and similar initiatives take on a particular significance. ${ }^{16}$ The experience of practising a participatory and deliberative democracy through these initiatives can help generate a sense of active sovereignty on the part of citizens. In this vein, Hind evokes what he sees as the potentially transforming effect of our participation in assembly:

'Our new power seems to be inside us. We experience a kind of exhilaration when we become conscious of our freedom. This exhilaration is visible to others. But this freedom-aspower is not our individual achievement or possession. It is a common property that depends on our being recognised by others as someone with a right to speak effectually, to be heard and to be reckoned with. This is the world-changing power. It is brought into being by our conferring public status on others through respectful attention, candid debate and attention to the common good.' (Hind 2014, 105). ${ }^{17}$

The research by Ishkanian, Glasius and Ali into the public square protests of 2011-12, offers some support for the idea that such activity can enhance participants' democratic agency: 'We found that in many instances, the move from the square led to a new period of activism; one which flew under the media radar and was concentrated in local neighbourhoods' (Ishkanian, Glasius, and Ali 2013, 10). Manuel Castells' study of the indignados makes similar points. He also emphasises equality within the assemblies; their 
highly deliberative character; and the way in which they prompted a wave of locally-based campaigning. ${ }^{18}$ Castells argues that the indignados experience achieved a 'true transformation in people's minds.' This claim relates directly to the idea of the active popular sovereign sketched above: 'If people think otherwise, if they share their indignation and their hope for change, society will ultimately change according to their wishes' (Castells 2012, 142). Castells argues that public opinion polls on the indignados in 2011 support the claim that the movement caused 'a cultural change' of this kind (Castells 2012, 142-143).

\section{Transnational republican politics?}

In an article on Occupy and the indignados, Philip Pettit argues that this politics is limited by its national focus (Pettit 2012b). Occupiers go to public squares of nation states and address national governments. But in fact much of the power of the interests they seek to challenge is located in a transnational space, and this calls for a politics that is correspondingly transnational. Pettit might argue that the focus of this paper remains, thus far, within the untenable bounds of 'fighting oligarchy in one country'.

In response, we can argue that Occupy-type action, and networked horizontalism more broadly, actually has considerable potential to help build a transnational republican politics. Recall that contemporary horizontalism has its roots in the alternative globalization movement that emerged in the 1990s and early 2000s. Occupy itself was a strikingly international movement. The initial call-out to occupy Wall Street in New York City was taken up by activists across many other nations. As the occupations got going, the range of nations involved increased. ${ }^{19}$ Social media helped people in one country follow events elsewhere and facilitated conversations across borders. Pettit suggests that opponents of 'plutocracy' in the EU might be better advised to organize 'marches across Europe' rather than 'mass gatherings in national squares' (Pettit 2012b, 180). But the simultaneous occupation of many national squares by a movement that is networked across countries has 
the potential to raise transnational issues and demands in a compelling way. Focusing specifically on the EU, one might argue that a network of linked occupations of national public spaces is in fact highly appropriate. In principle, it allows the movement to press claims in a complementary way at once at a number of levels, both to the EU directly and to national governments, the latter being of continuing importance given that the EU is in substantial part a system of intergovernmental cooperation, not straightforwardly a transnational polity. ${ }^{20}$ Kaldor and Selchow report that for participants in public assemblies in Europe in 2011/12, 'Europe' was an 'invisible' issue, and that, when pressed on the topic, many expressed sceptical views of the EU. However, this did not reflect a lack of a transnational perspective in the assemblies. Assemblies were typically following the activities of assemblies elsewhere and making supportive connections to many struggles around the world. Younger participants saw the EU as highly problematic as a political regime, but also took a social and cultural European identity, along with other identities, as a given (Kaldor and Selchow 2013, 91-95).

All of the categories of republican politics discussed above - prefigurative, defensive, and constitutional - can apply at a transnational level. Thus, horizontalist initiatives, perhaps manifesting in part in occupations of public spaces, might be seen as prefiguring the kind of republican democratic political relations that we wish to see at the transnational level. Horizontalist political action might also work as a defensive republican politics at this level. In what I have termed a defensive mode, such action can work not just on or through governments, but directly on major corporations by organizing transnational campaigns. Not least, horizontalist action might be used in support of a transnational constitutional republican politics. This would focus, amongst other things, on reforming the institutions of global and regional governance so as to weaken oligarchical power. In all of its dimensions, prefigurative, defensive and constitutional, such action might have the effect of developing 
participants' capacity to think about political and policy issues in transnational terms and, in this way, contribute to the development of new understandings of who 'We the people' are, which in turn can help lay some groundwork for new kinds of constitution and democratic politics at super-national levels.

At the same time, a constitutional republican politics can possibly help to nurture transnational perspectives. The issues about power and accountability raised in constitutional politics might require transnational initiatives for their solution. Existing supra-national institutions, like the EU, might become more of a focus of political action to the extent that questions about their basic rules are reopened. Kaldor and Selchow argue, in this vein, that '...Europe will only become visible within subterranean politics...by being problematized....Europe has to be linked to a new notion of 'democracy' - to establish itself as a creative space to re-imagine democracy' (Kaldor and Selchow 2013, 96).

\section{Conclusion: what are the opportunities for constitutional republican politics?}

Against the background of the oligarchical shift thesis, horizontalist political action can be linked to the ideal of republican democracy in four ways. First, it can prefigure republican democracy through egalitarian and deliberative internal practices. Second, it can offer a defensive republican politics, making full use of democratic elements of the existing constitution to push back against oligarchic influence. Third, it can help build a constitutional republican politics, a movement for institutional transformation that shifts the political baseline back towards republican democracy from oligarchy. Another aspect of this is the way it can potentially foster a stronger and wider sense of democratic capacity amongst citizens, of being properly a member of an active popular sovereign. Fourth, all of these functions, prefigurative, defensive and constitutional, can apply constructively at a transnational, as well as national, level. 
On the alleged impact of Occupy-style politics on citizens' sense of democratic agency, we have some supporting evidence. But it is admittedly tentative and we must acknowledge that not all the findings from the aforementioned studies are positive. As Ishkanian, Glasius and Ali report: '...in some instances, there was also a feeling among respondents that once the mobilizations in the squares ended and daily life resumed, that there was a betrayal of the spirit of the square and that some of the cohesion, unity and solidarity that existed in the square had now dissipated' (Ishkanian, Glasius, and Ali 2013, 10). This finding relates particularly to respondents involved in the Tahrir Square occupation and to this extent reflects the emergence of profound (and ultimately tragic) divisions within the revolutionary coalition that toppled Mubarak. But one might wonder if this disillusionment is a more widespread experience. Is the Occupy experience one of an initial sense of empowerment followed by frustration at limited achievements and, ultimately, a sense of disempowerment?

This question, which to some degree I must leave hanging here, is related to a point made at the end of section 4. If we think of Occupy and similar initiatives as constitutional republican politics, then its prospects probably can't be detached from questions about how far the wider political system allows opportunities for citizens to initiate and pursue meaningful constitutional deliberation and decision. There is an interdependency here: Occupy and similar initiatives can help create opportunities for constitutional change, but these initiatives are also likely to be supported and encouraged to the extent that the existing political framework provides opportunities for constitutional change. Where these opportunities exist, they can provide a point at which Occupy-style networks can connect to the formal political system with transformative as well as defensive intent. This suggests that the focus in this paper on the informal, horizontal citizen network and open, public assembly needs to be complemented by attention to institutional proposals to enhance opportunities for 
citizens to initiate constitutional change. Proposed institutions that would enable citizens to initiate deliberative processes on constitutional changes are at once part of the ends of Occupy-type political action, understood as a constitutional republican politics, and as a means to support and encourage it. ${ }^{21}$ Taken together, and developing greater transnational application to complement that at the national level, they can perhaps work in a mutually supportive way to counter the oligarchical shift and move polities closer to the ideal of republican democracy.

\section{References:}

Aitchison, Guy, 'Realist Disobedience? Protest, Coercion and the Limits of an Appeal to Justice', forthcoming.

Arendt, Hannah, 'What is Freedom?', in Hannah Arendt, Peter Baehr, ed., The Portable Hannah Arendt (Harmondsworth, Penguin, 2003), 438-461.

Bennett, W. Lance Bennett, and Segerberg, Alexandra, The Logic of Connective Action: Digital Media and the Personalization of Contentious Politics (Cambridge, Cambridge University Press, 2013).

Brown, Wendy, Undoing the Demos: Neoliberalism's Stealth Revolution (New York, Zone Books, 2015).

Castells, Manuel, Networks of Outrage and Hope: Social Movements in the Internet Age (Cambridge, Polity, 2012).

Cohen, Joshua, Rousseau: A Free Community of Equals (Oxford, Oxford University Press, 2009a).

------, Philosophy, Politics, Democracy: Selected Essays (Cambridge: MA, Harvard University Press, 2009b).

Crouch, Colin, Post-Democracy (Cambridge, Polity, 2003).

della Porta, Donatella, Can Democracy be Saved? (Cambridge, Polity, 2013).

Fox Piven, Frances, 'Interdependent power: Strategizing for the Occupy Movement', Current Sociology 62 (2), 2014, 223-231.

Franklin, Kaliya, 'Dear Prime Minister', October 21 2010, http://benefitscroungingscum.blogspot.com/2010/10/dear-prime-minister.html; 
------, 'To the Disabled People of Great Britain', October 23 2010, http://benefitscroungingscum.blogspot.co.uk/2010/10/to-disabled-people-of-greatbritain.html

Gerbaudo, Paulo, Tweets and the Streets: Social Media and Contemporary Activism (London, Pluto, 2012).

------, The Mask and the Flag: Populism, Citizenism and Global Protest (London, Hurst, 2017).

Gilbert, Jeremy, Common Ground: Democracy and Collectivity in an Age of Individualism (London, Pluto, 2014).

Gilens, Martin, and Page, Benjamin I., 'Testing Theories of American Politics: Elites, Interest Groups, and Average Citizens', Perspectives on Politics 12, 2014, 564-581.

Gitlin, Todd, Occupy Nation: The Roots, the Spirit, and the Promise of Occupy Wall Street (New York, HarperCollins, 2012).

Gourevitch, Alex, From Slavery to the Cooperative Commonwealth: Labor and Republican Liberty in the Nineteenth Century (Cambridge, Cambridge University Press, 2015).

Graeber, David, The Democracy Project: A History, a Crisis, a Movement (London, Penguin, 2012).

Greenwood, Arin, 'Lawrence Lessig: Occupy Movement Should Join Forces with Tea Party', Huffington Post, October 19 2011, http://www.huffingtonpost.com/2011/10/19/lawrencelessig-occupy-tea-party_n_1018844.html

Hacker, Jacob S., and Pierson, Paul, 'Winner-Take-All Politics: Public Policy, Political Organization, and Precipitous Rise of Top Incomes in the United States', Politics and Society 38 (2), 2010, 152-204.

------, Winner-Take-All-Politics: How Washington Made the Rich Richer - and Turned its Back on the Middle Class (New York, Simon and Schuster, 2011).

Harding, Eloïse, Conceptualising Horizontal Politics, (Ph.D thesis, University of Nottingham, Nottingham, 2012).

Hill, Symon, Digital Revolutions: Activism in the Internet Age (Oxford, New Internationalist, 2013).

Hind, Dan, Common Sense: Occupation, Assembly and the Future of Liberty (London, Myriad Editions, 2012a).

------, Maximum Republic (London , Free Commonwealth Editions, 2012b).

------, 'A Constitution for Europe', Al Jazeera English, June 62012 ,

http://www.aljazeera.com/indepth/opinion/2012/06/2012658135998757.html

------, The Magic Kingdom (London, Zero, 2014).

Ishkanian, Armine, Glasius, Marlies, and Ali, Irum S., Reclaiming Democracy in the Square: Interpreting the Movements of 2011-12, Department of Social Policy, London School of Economics, 2013, http://eprints.lse.ac.uk/53474/ 
Kaldor, Mary, and Selchow, Sabine, 'The 'Bubbling Up' of Subterranean Politics in Europe', Journal of Civil Society 9, 2013, 78-99.

Kina, Ruth, Prichard, Alex, and Swann, Thomas, 'Occupy and the Constitution of Anarchy', forthcoming.

Laborde, Cécile, 'Republicanism and Global Justice: A Sketch', European Journal of Political Theory 9, 2010, 48-69.

Landemore, Hélène, 'Inclusive Constitution-Making: the Icelandic Experiment', Journal of Political Philosophy, 23, 2015, 166-191.

Levi, Simona, '24M: It was not a victory for Podemos, but for the $15 \mathrm{M}$ movement', openDemocracy, June 9 2015, https://opendemocracy.net/can-europe-make-it/simonalevi/24m-it-was-not-victory-for-podemos-but-for-15m-movement

Maeckelbergh, Marianne, The Will of the Many: How the Alterglobalisation Movement is Changing the Face of Democracy (London, Pluto, 2009).

Marsh, Sue, '2011 - Year of the People', December 282010 , http://diaryofabenefitscrounger.blogspot.co.uk/2010/12/2011-year-of-people.html ------, 'Disabled people have become a force to be reckoned with', The Guardian, May 29 2012, http://www.guardian.co.uk/society/2012/may/29/disabled-people-political-force

Mason, Paul, Why It's (Still) Kicking Off Everywhere (London, Verso, 2013).

Maxwell, Lida, 'Democratic Dependency: A Feminist Critique of Non-Domination as Independence', in Yitfah Elazar and Genevieve Rousselière, Republican Democracy (Cambridge, Cambridge University Press, forthcoming).

Mazie, Steven V., 'Rawls on Wall Street', New York Times, Opiniator blog, October 212011 , http://opinionator.blogs.nytimes.com/2011/10/21/rawls-on-wall-street/?_r=0

McKeown, Maeve, 'Rape and the Occupy Movement', openDemocracy, December 14 2011, http://www.opendemocracy.net/ourkingdom/maeve-mckeown/rape-and-occupy-movement

Nabulsi, Karma, 'Mobilisation, Representation and Republican Movements', Renewal 16 3/4, 2008, 117-125.

Pettit, Philip, On the People's Terms: A Republican Theory and Model of Democracy (Cambridge, Cambridge University Press, 2012a).

------, 'Republican Reflections on the Occupy Movements', in Fintan O'Toole, ed., Up the Republic! Towards a New Ireland (London, Faber and Faber, 2012), 169-181.

Prentoulis, Marina, and Thomassen, Lasse, 'The legacy of the indignados', openDemocracy, August 13 2013, https://opendemocracy.net/can-europe-make-it/marina-prentoulis-lassethomassen/legacy-of-indignados 
Rawls, John, A Theory of Justice: Revised Edition (Cambridge: MA, Harvard University Press, 1999 [1971]).

Rousseau, Jean-Jacques, trans. by Christopher Betts, The Social Contract (Oxford, Oxford University Press, 1994 [1762]).

Slaughter, Steven, 'Transnational Democratization and Republican Citizenship: Towards Critical Republicanism', Global Constitutionalism 3, 2014, 310-337.

White, Stuart, 'What is the Place of Citizens' Assemblies in a Democracy?', in Bruno Leipold, Karma Nabulsi, and Stuart White, eds., Radical Republicanism: Recovering the Tradition's Popular Legacy (Oxford, Oxford University Press, forthcoming).

Winters, James, and Page, Benjamin I., 'Oligarchy in the United States?', Perspectives on Politics 7, 2009, 731-751.

Notes:

${ }^{1}$ See also the website of the British Academy project directed by Karma Nabulsi, Republicans Without Republics, http://users.ox.ac.uk/ polf0002/rwr/index.html

${ }^{2}$ For helpful discussions of networked horizontalism see Bennett and Segerberg 2013, Castells 2012, della Porta 2013, Gerbaudo 2012, 2017, Graeber 2012, Harding 2012, Hill 2013, Ishkanian, Glasius, and Ali 2013, Kaldor and Selchow 2013, Kinna, Prichard, and Swann forthcoming, Maeckelbergh 2009, Mason 2013.

${ }^{3}$ I explore the ideal further in a work-in-progress provisionally entitled Democracy over Wealth? Liberal Republican Political Economy. The basic shape of this conception of republican democracy owes much to Rousseau 1994. See also Cohen 2009a, 2009b.

${ }^{4}$ I do not define republicanism primarily in terms of freedom as non-domination. However, the individual's interest in non-domination (in not being subject to another's power of arbitrary interference) will feature in any plausible elaboration of individuals' shared basic interests at the centre of the common good. For a formulation of republicanism that puts freedom as non-domination centre-stage see Pettit 2012a.

${ }^{5}$ See Brown 2015, Crouch 2003, Gilens and Page 2014, Hacker and Pierson 2010, 2011, Winters and Page 2009.

${ }^{6}$ We return to this latter point in section 4.

${ }^{7}$ Gerbaudo emphasises that the initial social media campaign around the Adbusters call out was not effective. Social media became more effective once the camp was set up, with the Tumblr blog 'We are the 99\%' playing an important role.

${ }^{8}$ One should note also that recent protests are not always, or necessarily, only from the left or from disadvantaged or oppressed groups. 
${ }^{9}$ Lida Maxwell argues in her contribution to this volume that collective action to contest domination inevitably involves risks of 'democratic dependency' (Maxwell forthcoming). The practices I have described grappled with these risks, without altogether overcoming them.

${ }^{10}$ Adam Ramsay points out that of the 145 UK Uncut activists arrested for their protest occupation of Fortnum and Mason's shop on March 26 2011, about one third had at some point received training at the Summer Gathering of the student-focused campaign organization People and Planet.

${ }^{11}$ Unfortunately this study appeared after this article was substantially complete and so I have not had a chance to integrate it fully into the discussion. However, it offers an empirical interpretation of the movement of the squares, based on interviews with participants, that seems consistent with the normative, philosophical interpretation that I am suggesting.

${ }^{12}$ As Hacker and Pierson 2010 puts it (173, italics in original): 'The art for policy makers is not to respond to the median voter; it is to minimize the trade-offs when the desires of powerful groups and the desires of voters collide.'

${ }^{13}$ For an alternative perspective see Aitchison forthcoming.

14 One other way in which horizontalist action can support calls for fundamental constitutional change is through campaigns for national independence. One important example of this is the 2014 independence referendum campaign in Scotland.

${ }^{15}$ See Brown 2015 for a similar argument about the effect of 'neo-liberalism'.

${ }^{16}$ For a similar argument see Gilbert 2014, especially 176-179.

${ }^{17}$ On the idea of public liberty which seems implicit here see Arendt 2003.

${ }^{18}$ It might be objected that a move to locally-based campaigning is evidence against a postassembly sense of democratic empowerment at the constitutional level. However, this assumes that the participants see no connection between the two. But they may (rightly) do so.

${ }^{19}$ For the movement's own effort to list all of the Occupy camps around the world, see http://directory.occupy.net/

${ }^{20}$ On the idea of a multi-level republican politics, working for 'transnational democratization' and 'deepening public control of [the nation] state', see Slaughter 2014, drawing on Laborde 2010. For discussion of the national dimension of the movement of the squares see Gerbaudo 2017, 113-134.

${ }^{21}$ For relevant institutional discussions see Landemore 2015 and White forthcoming. For a discussion which points to the potential connection between participatory and deliberative politics in the informal, networked sphere and changes to democratic structures, see also della Porta 2013, 168-189. 